\title{
Disputas políticas e disputas por leitores: a criação do Correio da Manhã (1898-1901)
}

Lerice de Castro Garzoni

Rui e Edmundo lado a lado

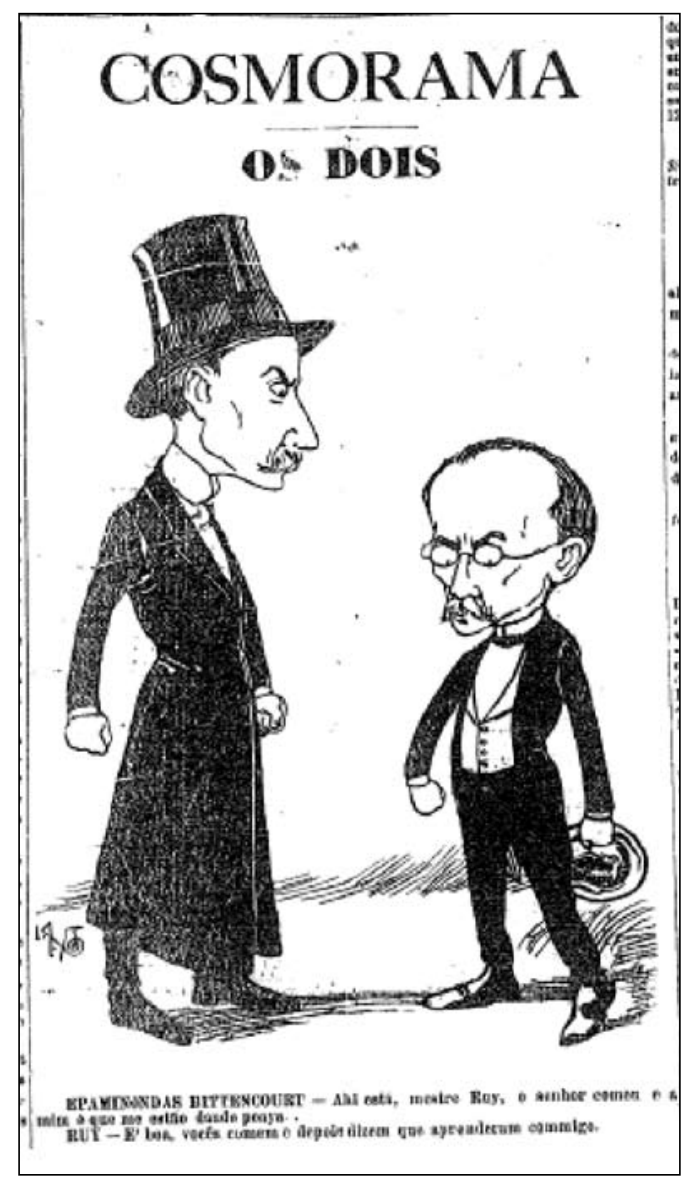

Epaminondas Bittencourt - Aí está, mestre Rui, o senhor comeu e a mim é que estão dando poaia.

Rui - É boa, vocês comem e depois dizem que aprenderam comigo. ${ }^{1}$

Em julho de 1901, um mês após o lançamento do jornal Correio da Manhãa, seu proprietário, o advogado Edmundo Bittencourt, foi caricaturado ao lado do Conselheiro Rui Barbosa na primeira página do periódico Cidade do Rio, de José do Patrocínio. Além de ter seus atributos físicos exagerados, os dois personagens apresentavam o semblante circunspeto e seus punhos cerrados, mostrando um sentimento de indignação mútua. Ainda que chamasse Rui Barbosa de "mestre", Bittencourt era representado reclamando uma injustiça, pois o emprego do verbo "comer" denuncia o recebimento de benefícios pecuniários por meio de fraudes. Segundo ele, portanto, Rui Barbosa havia "comido", sido corrupto, mas era Bittencourt quem era considerado culpado, "poaia", isto é, pessoa sem graça e sem sabor.

Naquele mesmo mês, Bittencourt já havia sido representado em outras caricaturas daquele jornal, ora como "D. Quixotino", ora como "Bacharel Epaminondas". ${ }^{2}$ Já Rui Barbosa, desde sua eleição para deputado geral, em 1879, havia sido personagem de diversas caricaturas espalhadas pelos jornais cariocas. $^{3}$ Naquele momento específico, o que unia os dois advogados era o caso das carnes verdes, daí o uso ambiguamente humorístico das expressões "o senhor comeu" e "vocês comem". 
No começo daquele ano, Rui Barbosa havia se envolvido em uma situação bastante delicada em relação à empresa que detinha o monopólio do comércio de carnes verdes na cidade do Rio de Janeiro. Contratado por essa empresa, a Salgado, Cardoso \& C., ele foi acusado de haver agido de má fé ao dar um parecer jurídico para uma empresa concorrente. Rui Barbosa foi criticado publicamente, sobretudo por meio da seção "Publicações a pedidos" do Jornal do Commercio, e respondeu nas páginas do jornal em que era editor-chefe, $A$ Imprensa.

Além de escrever artigos, sua estratégia de defesa envolvia a publicação de pareceres de diferentes juristas, com o intuito de mostrar que tinha o direito de dar o referido parecer e que não fora incorreto. O caso foi um escândalo na carreira do eminente advogado, sendo rememorado por seus inimigos políticos em outros momentos de sua trajetória. ${ }^{4}$ Também é um dos fatores evocados para explicar o fechamento do periódico A Imprensa, em março de 1901, além das dificuldades financeiras que a firma enfrentava desde o ano anterior.

Edmundo Bittencourt, por sua vez, mobilizara a questão das carnes verdes como tema da primeira campanha do recém-lançado Correio da Manhã. ${ }^{5}$ Trazendo a público o conteúdo de um inquérito instaurado em junho de 1900, Bittencourt questionava a qualidade da carne vendida pela empresa Salgado, Cardoso \& C., bem como a legitimidade do monopólio que ela detinha. A campanha provocou reações em quase todos os órgãos da imprensa carioca, angariando apoios e desafetos para o novo jornal.

Não demorou muito tempo para que seus adversários recordassem as ligações existentes entre o Conselheiro e Bittencourt, que havia trabalhado tanto no escritório de advocacia de Rui Barbosa, quanto na empresa jornalística $A$ Imprensa. ${ }^{6}$ Tendo em vista essas informações, a legenda da caricatura também ganha novos sentidos, já que "mestre" indica deferência e remete, ao mesmo tempo, a uma relação concreta de ensino e aprendizagem, tanto em relação ao ofício de advogado, quanto ao de jornalista.

O tema escolhido para a primeira campanha do Correio da Manhã desmoralizava a empresa de carnes verdes, mas isso não quer dizer que fosse, necessariamente, uma tentativa de "vingar" Rui Barbosa. Por outro lado, era evidente que, mais cedo ou mais tarde, essa campanha faria com que as ligaçóes entre Rui e Bittencourt viessem à baila. Principalmente se considerarmos que o novo periódico surgia, a partir da aquisição do espólio do jornal de Rui Barbosa, em que Bittencourt havia ocupado o cargo de secretário e publicado alguns artigos. Naquele momento, portanto, o proprietário da nova folha fazia questão de se associar ao nome de Rui, talvez pela publicidade que isso lhe proporcionaria. ${ }^{7}$

A aliança entre esses dois homens e, consequentemente, entre Rui Barbosa e o Correio da Manhã, seria bastante duradoura, o que pode ser comprovado no engajamento do jornal na Campanha Civilista de 1909-1910 e pela correspondência que trocaram até o início da década de $1920 .{ }^{8}$ Porém, especificamente no contexto de criação daquela nova empresa jornalística, é possível questionar se esse esforço para se manter tão explicitamente lado a lado com Rui corresponderia a um investimento em fazer do seu jornal uma continuidade do periódico anterior. Seria, afinal, um indício de que o Correio da Manhã e A Imprensa representavam um projeto único? Como cada um desses jornais foi definido por seus respectivos idealizadores?

Para refletir sobre essas questôes, parece fundamental entender um pouco do jornal que foi dirigido por Rui e que antecedeu o Correio da Manhã. Assim, na primeira parte do artigo, retomamos um pouco da história de $A$ Imprensa, com o foco sobre a participação do editor-chefe na publicação. Em seguida, observamos outras seções que compunham a folha e que, dialogando com os objetivos e a dinâmica dos veículos da chamada "grande imprensa", buscavam atingir leitores variados. Analisamos, portanto, desde seçōes dirigidas a públicos específicos, como "Petit Blues", até notícias de crime veiculadas pela folha, atentando para a forma como eram redigidas.

$\mathrm{Na}$ última parte do texto, retomamos o caso das carnes verdes e indicamos possíveis conclusões sobre as relaçôes existentes entre as duas folhas, principalmente em relação ao posicionamento político de seus idealizadores. Além de o Correio da Manhã ter sido formado do espólio de A Imprensa e de seu proprietário buscar manter e explicitar suas relações com Rui Barbosa, a defesa da revisão da Constitui- 
ção marcou a trajetória pública desses dois homens e, consequentemente, dos periódicos que dirigiram. Apesar de compartilharem essa militância, eles mobilizaram concepções distintas sobre seus leitores e, assim, diferentes estratégias para ampliar o público de seus jornais.

\section{Rui Barbosa e A Imprensa}

O primeiro número do jornal $A$ Imprensa veio a público no dia 5 de outubro de 1898 . Sua organização ficou a cargo de Carlos Viana Bandeira, cunhado de Rui Barbosa, enquanto este ocupava o cargo de editor-chefe. Os autores que escreveram sobre a vida de Rui Barbosa destacam o período em que ele colaborou nesse periódico como um retorno à atividade jornalística. ${ }^{9}$ Porém, alguns estudiosos destacam que sua participação no novo periódico se restringiu aos artigos publicados na "coluna de honra", pois não interferia ativamente no conteúdo do jornal como um todo, nem ia à redação com frequência. ${ }^{10}$

Independente disso, o jornal gozava do prestígio de ser associado ao nome de tão ilustre figura. $\mathrm{Na}$ nota que anuncia o aparecimento de $A$ Imprensa, a Gazeta de Notícias ${ }^{11}$ nomeia o novo jornal como "folha do sr. dr. Rui Barbosa", que desperta interesse do público, "a quem o eminente brasileiro já impôs a necessidade de sua pena". O Jornal do Commercio também recorre a essas referências: "dizer que seu diretor é o Dr. Rui Barbosa é recomendá-lo à respeitosa consideração de quantos se ocupam das coisas públicas do nosso país, do seu progresso e de todas as causas a cujo serviço ele tem prestado o poderoso concurso da sua inimitável pena." 12

Esses jornais comentavam o surgimento da nova folha destacando a dimensão do artigo de apresentação, "Projetos e esperanças", que ocupava toda a primeira página e parte da segunda. No texto, Rui fazia considerações sobre a missão do jornalismo e defendia a revisão da Constituição Brasileira. Embora tenha declarado que "entre uma presidência que expira e outra que se espera, não pode existir em nós a mesma predisposição combatente", não tardou para que o jornal iniciasse sua oposição ao governo de Campos Salles. Tanto que, no final do mês de outubro de 1898, logo após assumir a presidência da República, Campos Salles enviou uma carta a Rui dizendo que "A Imprensa é o meu café de todas as manhãs, e às vezes um tanto amargo; mas sempre benéfico". ${ }^{13}$

No início do ano seguinte, Rui Barbosa publicou uma série de artigos criticando os monopólios estabelecidos na cidade do Rio de Janeiro e solicitando um posicionamento do governo municipal. $\mathrm{O}$ abastecimento de água, a coleta do lixo, o fornecimento de gás e eletricidade e o serviço telefônico foram os temas abordados ao longo do mês de janeiro de 1899, em artigos que comparavam a qualidade e a administração desses serviços na capital brasileira com os fornecidos em cidades norte-americanas e inglesas.

No mesmo período, Rui escrevia sobre a economia do país, discutindo a taxação de mercadorias importadas e o procedimento do governo em relação aos credores da dívida nacional. Além de colocar essas questôes em debate, Rui respondia aos ataques recebidos de outros órgãos de imprensa que criticavam sua postura, quando fora ministro da Fazenda do Governo Provisório (1889-91). O emprego do jornal para a defesa do seu editor-chefe seria uma característica recorrente nesse periódico. ${ }^{14}$

Publicados diariamente, os editoriais de Rui passaram a aparecer de forma irregular e espaçada a partir do final de 1899, devido aos problemas de saúde que ele enfrentava. Foi durante uma dessas "licenças”, em março de 1900, que ocorreu uma suposta conspiração contra o regime republicano. Mais do que depressa, Rui retomou o seu posto e publicou uma série de artigos sobre essa tentativa de restauração monárquica - batizada de "A Pavorosa" pelos órgãos da imprensa -, sempre criticando a suspensão dos direitos constitucionais, tendo em vista a atuação arbitrária da polícia, e sugerindo que a tentativa de golpe não passava de uma farsa do governo. Nesse momento, tomou a defesa de Andrade Figueiredo, um velho militante monarquista que teve sua casa violentamente invadida. Em um dos artigos, Rui assevera:

Sempre foi nossa regra não medir as consequências das situações, a que o dever nos adscreve. Por isso arrostamos a peito descoberto, em 1891, em 1892, em 1893 o marechal de ferro. Por isso, de 1893 a 1895, tive- 
mos de engolir dois anos de desterro. Por isso, em 1895, não trepidamos em atiçar o braseiro ainda aceso dos ódios florianistas, opondo a guerra, que opusemos, à falsa anistia imposta pelo sr. Prudente de Morais ao senado. (...) Nunca houve causa vencedora, que nos seduzisse, nem causa periclitante, de que fugíssemos. ${ }^{15}$

Além de defender Andrade Figueiredo, e por vezes se autodefender nas páginas de A Imprensa, Rui Barbosa relatava a sua trajetória entrelaçando-a à história da república. Trata-se, portanto, de uma autobiografia que constrói uma memória sobre o regime, ao mesmo tempo em que confere legitimidade ao seu autor. ${ }^{16}$ Apesar de Rui declarar que a cobertura dessa conspiração aumentou a venda de $A$ Imprensa, forçando a impressão de várias tiragens diárias, em abril de 1900 o jornal foi obrigado a fechar as suas portas por dificuldades financeiras. ${ }^{17}$ Foi nessa conjuntura que Edmundo Bittencourt expressou, pela primeira vez, seu interesse pela compra do jornal, mas foi o companheiro de escritório de Rui Barbosa, o advogado Ulisses de Carvalho Soares Brandão, que reorganizou a empresa e foi o responsável por sua reabertura em agosto de $1900 .^{18}$

No artigo de abertura da segunda fase, o editor-chefe critica a imprensa que "atrofia a sua missão educadora" e reafirma seu propósito de promover uma "campanha liberal", defendendo a justiça como princípio fundamental da República. Pelos jornais de todo o país, foram várias as saudaçôes ao seu reaparecimento, inclusive em Cidade do Rio, de José do Patrocínio, que tantas vezes combateu as opiniões veiculadas por $A$ Imprensa. ${ }^{19}$

Após a reabertura do jornal, Rui Barbosa se ocupa de um assunto que vinha sendo discutido no senado: o projeto do divórcio. Desde o início, ele se posicionou contra esse projeto que, segundo ele, não representava os "sentimentos do país, seu estado social, sua consciência moral e religiosa" ${ }^{20}$ Inicialmente, questionou o autor da proposta, o senador Martinho Garcez, censurando os rumos que a discussão vinha tomando no senado brasileiro e, nos artigos seguintes, se dedicou a descrever a situação de países que aprovaram o divórcio. Recorrendo a autores estrangeiros, discorre sobre a situação da França, dos Estados Unidos, da Alemanha e da Inglaterra.

A defesa da família, da lei cristã e da moralidade é uma constante nesses escritos que destacam as consequências negativas do divórcio para a maternidade e para as relaçôes matrimoniais. É interessante notar que, no Governo Provisório, Rui havia sido o autor do projeto de lei, aprovado em janeiro de 1890, que visava à separação entre Igreja e Estado. Com o objetivo de não criar atritos com a Igreja, a questão do casamento civil e dos registros de nascimentos e óbitos ficou relegada a uma legislação posterior, ${ }^{21}$ o que quer dizer ter sido o próprio Rui que deixara uma "brecha" para que uma proposta como aquela surgisse naquele momento.

À mesma época desses artigos sobre o divórcio, Rui trouxe a público uma denúncia feita por um deputado contra o ministro da fazenda, Joaquim Murtinho. Não era a primeira vez que expressava reprovação às atitudes de Murtinho, extensão da sua oposição ao governo de Campos Salles. Nesse caso específico, porém, a acusação tocava às raias do pitoresco já que, segundo ele, retratos de meretrizes haviam sido impressos nas notas do tesouro. Para Rui, tratava-se de um caso de "gravidade tremenda", sendo desmoralizante "ver nas cédulas do tesouro, sob o emblema da república, as feições de uma messalina". ${ }^{22}$

Em fins de 1900, Rui Barbosa denunciava que o jornal vinha sendo boicotado e que temia pela sua segurança. Ele lembrava que, embora houvesse feito oposição na imprensa aos ministérios João Alfredo e Ouro Preto durante o Império, assim como à ditadura de Floriano Peixoto, no novo regime, não haviam ocorrido ameaças contra os periódicos nos quais colaborara, como presenciava, naquele momento, em relação a $A$ Imprensa, ainda que sua oposição ao presidente Campos Salles fosse bem menos enérgica. Segundo ele:

há, nesta terra, um jornal, que presentemente os vendedores não apregoam: é $A$ Imprensa, outrora um dos mais apregoados. Se esta singularidade, reservada exclusivamente a nós, não é um artifício sutil, mas terrível, para nos afogar a circulação, di-lo-á o critério dos homens sensatos. Destarte os vendedores de folhas sacrificam os seus próprios interesses, ligados ao aumento crescente da vendagem. ${ }^{23}$ 
Provavelmente, há certo exagero de Rui, pois, independentemente do suposto boicote, a vendagem não estava tão crescente quanto apregoava. Assim, a despeito das questôes políticas envolvidas, a situação financeira do jornal não se manteria por muito tempo; em março de 1901, foi obrigado a cessar sua publicação definitivamente. Antes disso, porém, dois escândalos marcaram a vida da folha e de seu editor-chefe. Um deles, como vimos, foi o envolvimento de Rui Barbosa no caso das carnes verdes, colocando em xeque a sua honestidade profissional, que o levara a publicar uma série de pareceres de juristas, sob o título "Carnes Verdes", ao longo dos meses de janeiro e fevereiro de 1901.

O outro escândalo diz respeito à colaboração do senador Fausto Cardoso na folha. Ele havia sido convidado para escrever em $A$ Imprensa em fevereiro de 1901, mas, já no início do mês seguinte, publicou o artigo "Fiquem-se", desligando-se do jornal de forma abrupta. O caso ganhou repercussão porque, em vez de procurar outro órgão de imprensa para expressar seu ressentimento, ele o fez nas colunas do próprio jornal que atacava. Isso mostrava a fragilidade da organização do periódico, cujos responsáveis deixaram passar um texto daquele teor, extremamente ofensivo aos editores do jornal. Para se defender das acusações que Fausto Cardoso passou a publicar no jornal O Dia, segundo as quais a atuação de Rui no jornalismo seria condicionada por seus “interesses pecuniários”, ele diz:

Não sou, nunca fui dos que dão à imprensa, pelos interesses pecuniários que ela lhes dá. Tenho trabalhado no jornalismo quase sempre gratuitamente. De 1871 a 1878 servi constantemente como redator e, por muitos anos como redator em chefe do Diário da Bahia (...) Em 1889 fui chefe da redação do Diário de Notícias (...) Tive, mais tarde, em 1893, a chefia na redação do Jornal do Brasil, e ali escrevi diariamente (...) Agora, A Imprensa. ${ }^{24}$

Novamente, Rui Barbosa retoma elementos da sua biografia, dessa vez destacando sua atuação em diferentes jornais ao longo de sua vida pública. De certa forma, buscava mostrar como a sua própria história de vida se confundia com a história do periodismo desde o Império. Entretanto A Imprensa, cuja segunda fase completava cinco meses, não resistiria aos ataques: o conflito entre os dois senadores, aliado à delicada situação econômica da empresa, determinaria seu fechamento naquele mesmo mês de março de 1901 .

\section{Dos leitores seletos...}

No artigo de apresentação da segunda fase do jornal, em agosto de 1900, Rui Barbosa mostrava insatisfação em relação aos leitores brasileiros: "somos uma nação que mal lê. Miserável é, em nossa terra, a porcentagem dos que sabem ler; e, dentre os que se adereçam com essa prenda, grandíssimo o número dos que, por indiferença, ou preguiça, pouco a aproveitam." 25 Consideraçóes semelhantes foram feitas quando, por ocasião da visita de Campos Salles à Argentina, Rui compara a imprensa dos dois países, afirmando que, no Rio de Janeiro, "certa quantidade permanente, quase invariável, de leitores flutua de umas folhas para outras (...) sem deixar de ser a mesma, apenas diversamente repetida (...) o número dos que lêem não aumenta" ${ }^{26}$

Essas constatações do editor-chefe não inviabilizavam a mobilização de algumas estratégias, por parte de outros editores e redatores envolvidos na produção da folha, para ampliar, ou ao menos diversificar, os leitores de $A$ Imprensa. Tratava-se de aumentar a influência política do jornal, mas também, ou principalmente, de evitar a crônica situação de penúria da empresa. Em parte, a própria presença de Rui já contava como publicidade para o periódico; por outro lado, era necessário que, a exemplo dos seus concorrentes, o jornal oferecesse alguns atrativos e diversão para seus clientes. Assim, tanto no início do ano de 1899, quanto no de 1900, os leitores eram informados sobre os brindes destinados àqueles que fizessem novas assinaturas. ${ }^{27}$ Nesse mesmo sentido, o jornal oferecia a tradução de livros em forma de folhetins, como o romance polonês A ferro e fogo, publicado a partir de outubro de 1900 .

No início desse mesmo ano, o jornal havia empreendido uma detalhada cobertura sobre a viagem da escritora espanhola Eva Canel $^{28}$ ao Brasil. Foram publicadas as transcrições das conferências que ela 
proferiu, bem como matérias a respeito de suas impressóes sobre os brasileiros e sobre o Rio de Janeiro. Aquela senhora, "tão fecunda de produções mentais e sem o ar bisonho e hepático das pessoas aplicadas ao cultivo da inteligência", ${ }^{29}$ havia pronunciado palestras sobre a situação da Espanha e sobre a raça latina, mas foi a que proferiu sobre o feminismo que suscitou um diálogo nas páginas de $A$ Imprensa. Dias após a publicação do discurso "Algunas reflexiones sobre el feminismo", foram publicadas as cartas trocadas entre Maria Guilhermina Loureiro de Andrade e Eva Canel. Segundo o jornalista que as apresentou, eram "documentos curiosos por se referirem a questóes da atualidade". ${ }^{30}$

Maria Guilhermina saudava a escritora e dizia que desconhecia a existência de feminismo no Brasil, ainda que visualizasse uma busca crescente pela educação feminina, da qual era defensora. Em conformidade com a palestra que havia proferido, Eva Canel colocava limites a essa busca, dizendo não ser contra a instrução feminina, mas que isso só deveria acontecer depois que a mulher tivesse assegurada a sua educação moral. Para elas, a discussão em torno do significado do feminismo implicava a definição do papel da mulher na sociedade.

Em crônica intitulada "As brasileiras", publicada no mês seguinte, Eva Canel lembrava que "no Brasil, há mais, muitíssimo mais que os produtos vegetais, há mulheres instruidíssimas” ${ }^{31} \mathrm{e}$, entre elas, destacava o caso de Julia Lopes de Almeida ${ }^{32}$ que, além de livros, havia publicado muitos artigos, ainda que de forma irregular, em jornais. Divulgada no semanário argentino La Mujer, essa crônica havia sido traduzida e transcrita para as páginas de $A$ Imprensa. Além de tratarem de "questôes da atualidade", ou de despertarem a curiosidade em seus contemporâneos, a presença de textos escritos por mulheres, bem como os temas abordados, evidencia que o jornal buscava atingir um público variado.

A seção "Carteira de um jornalista", de Jacques Bonhomme, pode ser lida nesse mesmo sentido. Em uma das crônicas, ele comentava o impacto da guerra da África do Sul sobre a vida social do Rio de Janeiro:

(...) chefes de família exemplares, donas de casa todas consagradas ao lar e aos filhinhos e até as criadas e os criados deram em alistar-se platonicamente nas fileiras do general Joubert ou nas milícias do general Buller. Não há quem não tenha uma opinião sobre o conflito (...) A maior parte não sabe lá muito bem onde fica a Inglaterra e muito menos o Transvaal, mas isso não impediu ontem o meu engraxate de comunicar-me que achava próxima a rendição da tadisumita $\left[\right.$ sic] ${ }^{33}$

As opiniōes sobre o conflito distante se formavam a partir das notícias publicadas nos jornais que, segundo o cronista, circulavam por meio sociais muito distintos. A partir disso, ele conta o caso de uma "família respeitável" na qual a sogra, assídua leitora de jornais nacionais e estrangeiros, transformou a casa em um verdadeiro campo de batalha. Por conta do envolvimento da senhora com as notícias, os esposos haviam tomado posicionamentos diversos em relação à guerra e pensavam em requerer o divórcio "por incompatibilidade de gênios". Até a vida da criada havia sido afetada:

Os preliminares do conflito traduziram-se na despedida de Maria, uma criada portuguesa, que estava na casa ia em três anos. Tinha chegado nesse dia o correio da Europa e a velha recebera o Ilustred London News. À noite, enquanto a família examinava os retratos dos oficiais britânicos mortos e feridos em Giencoe, a pobre rapariga, que aguardava as ordens para as compras do dia seguinte, olhando por acaso por cima do ombro da sinhazinha deu com a fotografia de um $2^{\circ}$ tenente dos Gordon Highlanders, tipo de beleza varonil e levada pela sua natureza de campônia alentada não pode conter-se que exclamasse: "Que lindo moço!" (...) A velha, feia como um susto à meia noite, como se diz no Rio Grande, ficou horrenda. Empalideceu, enrubesceu, virou verde e afinal destemperou: "Sua atrevida... (...) Sua sem vergonha! Você julga que isto aqui é casa de mulheres... Foi essa a criação que sua mãe lhe deu?!... Ora faça favor de mudar-se... e já... e olhe que lhe quero ver a trouxa... Você, que gosta dos ingleses, é bem capaz de fazer à roupa branca dos patrões o mesmo que eles fizeram às nossas colônias...” Para d. Prudência, todas as colônias, falando-se dos ingleses, tinham sido nossas. ${ }^{34}$

Por um lado, é bastante provável que a cena descrita por Jacques Bonhomme não passasse de um produto de sua imaginação ou de um boato zombeteiro que corria à época, reproduzido na crônica com 
o objetivo de entreter e fazer rir os seus leitores. Afinal, como ele próprio define, "a crônica, uma bola de sabão, contenta-se com muito pouco e mais vive da disposição da luz que da solidez dos conceitos" ${ }^{35}$ Por outro lado, essa cena doméstica nos ajuda a vislumbrar um momento em que as notícias dos jornais poderiam ser compartilhadas entre uma família e seus agregados, permitindo que cada um formasse sua opinião sobre os assuntos veiculados nas mais diversas folhas.

Em alguns momentos da série de artigos, Jacques Bonhomme destacava que se dirigia, tanto aos homens, quanto às mulheres, chegando a responder à carta de uma mãe que pedia orientações sobre a carreira do filho. ${ }^{36}$ Essa carta poderia ser uma invenção do autor, mas o fato de uma leitora intervir e participar no jornal não era algo inverossímil, já que várias delas responderam, por exemplo, ao pedido de subscrição "para suavizar os horrores de uma triste miséria". ${ }^{37}$ Às vezes, a folha noticiava as festas promovidas por distintas senhoras ou a viagem de estudos de alguma senhorita. ${ }^{38}$ Em se tratando do público feminino, encontramos desde anúncios de roupas e chapéus, a tônicos para cabelos e doutoras especializadas em "moléstias de senhoras".

Contudo, seria em "Petits Blues", escrita em francês e assinada por Santuzza e Suzette, que as leitoras encontrariam uma seção destinada especialmente a elas. ${ }^{39}$ Inicialmente, a coluna era composta pelas cartas que Santuzza destinava à "Mme. X" ou à "Mlle. Z", respondendo às suas dúvidas e distribuindo conselhos. O caráter epistolar reforça a ideia de que as leitoras poderiam interferir na própria elaboração do jornal, particularmente daquela coluna. Suzette estreia um pouco depois, escrevendo crônicas e, por vezes, sendo alvo dos conselhos de sua companheira de seção. Com o passar do tempo, a leitora descobre que Santuzza é uma mulher mais velha e viúva, mãe do pequeno Raoul. Sobre Suzette, é possível saber que havia colaborado em jornais em seu país de origem, a França. Essas foram as poucas características mobilizadas para distinguir e conferir personalidade às personagens-narradoras da seção. ${ }^{40}$

Apesar de concentrada no "universo feminino", não seria correto interpretar essa seção como algo independente do jornal, como uma pequena "revista feminina" incrustada em um contexto ao qual fosse indiferente. Afinal, Suzette estabelecia diálogos com outras colunas de A Imprensa, comentando artigos de Jacques Bonhomme, por exemplo, ou suscitava a reação de colegas de outras folhas, como a resposta que "Gatinho" lhe escrevera na Gazeta de Noticias. ${ }^{41}$ Como dissemos acima, Suzette não aconselhava, mas escrevia a respeito de temas diversos que se relacionassem às mulheres, como moda e educação. Com isso, a leitura da coluna levava ao interesse por outras partes do jornal e vice-versa. ${ }^{42}$

Após a interrupção do jornal, tanto "Carteira de um jornalista" quanto "Petits Blues" não voltariam a ser publicados, possivelmente pela dispensa dos respectivos responsáveis, com o intuito de cortar gastos. No final de agosto de 1900, porém, uma nova seção em língua francesa passava a ocupar a primeira página de $A$ Imprensa. "Croquis Politiques", assinado por Iwan d'Hunac, pseudônimo de João Itiberê da Cunha, tratava de forma leve e descontraída a vida política do país. Alguns dias após o artigo em que Rui Barbosa denunciava a imoralidade de ver os retratos de messalinas impressos nas notas do tesouro, Iwan transcreve o "dialogue entre billets de banque":

Vênus de $2 \$:$ Tu vois, je suis modéste, mes aspirations sont celles d'une petite bourgeoise, je me contente du peux que je vaux.

Vênus de 50\$: Tu es bête, loulou! Quand on arrive à forcer les portes du trésor c'est que de moins qu'on figure sur quelque chose de valeur... même fictive!

Vênus de 2\$: Bah! On nous brûlera un de ce jour pour complaire a mr. Funding et, plus, que restera-t-il de notre éphemère grandeur?

Vênus de 50\$: Il restera le tintanierre glorieux que nous avons dechaîné parmi nos gros lapins chéris, les péres de la patrie... Après tout, c'est déjà beau! As-tu vu comme ils se sont chamaillés?

Venus de $2 \$$ : Et comme nous avons été insultées aussi!...

Ah! Que les homes sont taux! Nous devrions leur faire payer ça!

Venus de 50\$: Le plus tôt possible, quand ils viendront soupirer à nos pied leurs fadaises idiots: "mon petit chat, mamour!" Ils en verront de vertes, maintenant, je te le promets!... ${ }^{43}$ 
Dos rostos de meretrizes nas notas à desvalorização do dinheiro brasileiro em decorrência do Funding Loan, o cronista coloca em xeque a moral dos senadores e deputados, que seriam íntimos daquelas "vênus", e a quem elas juravam vingança. Em dezembro de 1900, Iwan passa a assinar a seção "Petits mots du matin", na qual escreve como se estivesse publicando as cartas que dirige a sua prima Yvette, na França. Inicialmente, mantém os assuntos políticos, apenas adaptando-os a uma interlocução feminina. ${ }^{44}$ Depois, passa à descrição da cidade do Rio de Janeiro, até anunciar, no início de 1901, que "mon adorable cousine Yvette me prie (pour moi c'est un ordre), d'ouvrir une section de lettres féminines sur l'actualité des modes". ${ }^{45}$

A partir de então, a seção ganha o subtítulo de "Lettres féminines" e passa a publicar cartas que, supostamente, teriam sido enviadas pelas leitoras. Após a publicação de quatro cartas, Iwan comunica à prima que a ideia não funcionou. Essa conclusão parece bastante precipitada e, provavelmente, está mais relacionada à conjuntura do jornal que à recepção da seção em si. Afinal, Iwan deixaria de escrever para o jornal a partir do mês seguinte. Talvez, o escritor por atrás do pseudônimo tivesse sido dispensado e, dentro em breve, a própria empresa desapareceria.

\section{... aos mais "populares"}

Nas suas memórias, Carlos Viana Bandeira comentava que "Rui era avesso a tudo que pudesse ferir o feitio material do órgão", cuja principal inspiração estava no periodismo inglês. Bandeira, por sua vez, lamentava o fato de não poder reproduzir o padrão das folhas francesas, como Le Figaro ou Le Matin, ou "a variedade e a leveza dos novos diários americanos", acrescentando que "por mim, haveria em $A$ Imprensa não só farta ilustração, como vários redatores, cada qual com a sua própria seção" acrescentando que "sairiam retratos de artistas e abundantes notícias correlativas". ${ }^{46}$

Apesar de o jornal seguir o modelo estabelecido pelo editor-chefe, prezando a presença maciça de textos, uma seção ilustrada foi introduzida no mês de março de 1900. Em "Instantâneos", há o desenho, a descrição e uma série de elogios a alguns artistas que atuavam nos teatros da capital. No dia 4, temos o retrato de Lucila Simões e, no dia seguinte, o de Lucinda Simões. Em 10 de março, a ilustração representa Cristiano de Souza que, segundo a nota, "tem o talento de dez e estuda por cem". Essa iniciativa, porém, não contaria mais de três dias.

Outra tentativa de inserir ilustrações seria efetuada no mês seguinte, com a seção "Contemporâneos". Ela era composta por charges que satirizavam situações cotidianas e, curiosamente, algumas envolvendo mulheres ${ }^{47}$ mas que não tinham ligação alguma com as matérias do próprio jornal. Enquanto "Instantâneos" pretendia celebrar artistas, "Contemporâneos" buscava provocar o riso. Mesmo tendo objetivos diversos, nenhuma das duas sobreviveria por muito tempo.

Essas tentativas frustradas de diversificar o conteúdo e a diagramação do jornal podem ser tomadas como evidências de que a concepção de Rui sobre o "feitio material do órgão" foi posta em prática. Por outro lado, é possível questionar se o mesmo ocorreu com o conteúdo de certas seçôes, particularmente as policiais. No artigo de apresentação do jornal, Rui ponderava que:

Embora o comércio tenha invadido em larga escala estes domínios, levando o periodismo a degenerar no industrialismo e, se nos permitem o termo, no sensacionalismo americano, na idolatria da notícia, no culto do escândalo, na exploração dos baixos apetites da curiosidade, esses desvios nunca aumentaram a autoridade à imprensa, da qual no país onde mais prosperam o bom senso das classes pensantes os indigita como o descrédito e a peste. ${ }^{48}$

Apesar das críticas ao "sensacionalismo" e ao "culto do escândalo", os jornalistas responsáveis pelas notícias policiais veiculadas em $A$ Imprensa empregariam uma linguagem muito próxima àquela vista em outros jornais que, segundo Rui, alimentavam os "baixos apetites da curiosidade". Assim, muitas das notícias de crime em $A$ Imprensa incorriam nos erros execrados pelo editor-chefe na carta programa. No início de 1899, sob o título "Suplício Inquisitorial - A fogo de petróleo - A impunidade", lemos: 
Desde muitos dias que o nosso repórter incessantemente trabalhava na descoberta de um tremendo crime, ocorrido há cerca de três meses, em um dos lugares mais públicos desta capital, e que, entretanto permanecia envolto no maior mistério, até para a nossa polícia que só hoje terá conhecimento dele pelas nossas colunas. ${ }^{49}$

Um crime misterioso, que escapava ao conhecimento da própria polícia, seria devidamente esclarecido pelo repórter. Porém, o início da notícia, em vez de informar o ocorrido, foi todo dedicado a relatar as dificuldades enfrentadas pelo repórter, enfatizando seu trabalho incansável e seu empenho. A esse preâmbulo sobre a atuação do jornalista, seguem-se os antecedentes do fato criminoso:

Narcisa Maria da Conceição era parda, de 30 anos de idade. Enquanto aqui esteve seu irmão, portou-se mais ou menos honestamente, mas assim que ele partiu para a Bahia amasiou-se com Alfredo, o Ceguinho. Nesta união, durante o dia, cada um andava para seu lado, reunindo-se sempre à noite, depois de passarem algumas horas em libaçóes na taverna do Manoel Vaqueiro, à rua de D. Manoel n. 66. Depois retiravam-se para a lôbrega casa de dormida do Lisboa, no Beco dos Ferreiros n. 9. E, deitavam-se numa infecta esteira no meio da mais nojenta e horrorosa promiscuidade com indivíduos da mais baixa espécie - homens e mulheres - que em grande número, ali passavam a noite. Um dia, cansados de certo dessa espelunca, abandonaram-na e foram residir para uma estalagem da rua de Santa Luzia, onde, uma noite, a vizinhança despertava, sobressaltada, aos gritos assustadores de socorro e de fogo, que partiam da casinha ocupada por Narcisa e Alfredo, o Ceguinho. ${ }^{50}$

Nesse trecho, o comportamento de Narcisa e as condições de vida do casal eram colocados sob o julgamento do leitor. Narcisa, que, antes, comportava-se "mais ou menos honestamente", passara a ter uma vida completamente desregrada, após perder a tutela do irmão. Amasiada com Alfredo, vivia "horas em libaçôes na taverna" e dormia em uma "lôbrega casa de dormida", "no meio da mais nojenta e horrorosa promiscuidade". Porém, essas informações não tinham relação alguma com o crime em si, que aconteceu quando o casal habitava a casinha de uma estalagem. Após descrever que a vizinhança acordou com os "gritos assustadores de socorro e de fogo", a notícia continua:

Numerosas pessoas acudiram logo humanitariamente e aí encontraram já o corpo da infeliz Narcisa todo queimado sobre a enxerga onde jazia. $\mathrm{O}$ fato passou como um acidente e, no entanto fora um monstruoso crime. Narcisa tivera, momentos antes, uma forte discussão com o amante e este miserável, incendiário e assassino, calando-se, logo após, na premeditação da mais covarde e cruel das vinganças, deixou a pobre rapariga acomodar-se e quando viu que ela dormia a sono solto, despejou-lhe querosene nas vestes e prendeu-lhe fogo! A vítima quando despertou estava toda em chamas e mal pode soltar débeis gritos, caindo em seguida morta. ${ }^{51}$

$\mathrm{Na}$ descrição do "monstruoso crime", os adjetivos têm um papel fundamental, pois ajudam o jornalista a detalhar cada um dos fatos e personagens que compunham a cena. Toda a narração, aliás, foi cuidadosamente construída, partindo de um crime misterioso, passando pela trajetória do repórter e dos protagonistas e chegando, enfim, ao desfecho trágico. A notícia continua com os depoimentos de pessoas que presenciaram o crime, colhidos informalmente pelo repórter e pelo irmão da vítima. Nas páginas do pretensamente sisudo jornal do Conselheiro, que criticara o "sensacionalismo", muitas outras narrativas empolgantes sobre crimes teriam espaço.

O caso que acabamos de acompanhar é particularmente elucidativo do alcance dessas notícias porque mostra que, além de atrair leitores pelo estilo, divulgavam padrões de comportamento e moralidade. Muitas vezes, nas agressões entre casais, a mulher era apresentada como vítima. ${ }^{52}$ No caso de Narcisa, apesar de ter sofrido o ataque, ela também teve sua conduta censurada pelo autor da notícia. ${ }^{53}$ Isso não quer dizer, no entanto, que o jornal propagava uma ideia monolítica de moral. Afinal, as próprias representações de "vítima", ou de "agressora", poderiam ter valoraçôes diversas em diferentes momentos. Em "Mulher para dois", lemos:

Não vão julgar pelo título que se trata da comédia que figura nos anúncios de um dos nossos teatros. Relata-se simplesmente o fato de Maria Paula Vieira, brasileira, moradora à rua do Lavradio, n. 42 e que - "per- 
seguida e desrespeitada" - conforme as suas declarações na delegacia da $7^{a}$ circunscrição, por dois soldados de polícia, bateu-se valentemente com ambos, pondo-os fora de combate. ${ }^{54}$

Moradora à Rua do Lavradio, havia uma grande chance de essa mulher ser uma meretriz. Ainda assim, por agir em defesa de sua honra, a atitude de Maria Paula foi qualificada como "valente", implicando a agressão a dois praças de polícia. Mas, além da "defesa da honra", outros fatores podem ser mobilizados para entender porque essa mulher foi qualificada dessa forma. Nesse sentido, vale lembrar que a maior parte dessas notícias policiais eram redigidas a partir de informaçóes obtidas nas delegacias de polícia. Como havia inúmeros atritos entre as diferentes instituições responsáveis pelo policiamento da cidade, ${ }^{55}$ o fato de Maria Paula ter agredido soldados - ou seja, autoridades de uma instituição "concorrente" - pode ter sido visto com "bons olhos" pelos policiais que registraram a ocorrência. De alguma forma, o olhar dos policiais pode ter influenciado o julgamento do próprio jornalista.

Já em "Mulheres Diabólicas - A faca e pau" ${ }^{56}$ o repórter narra o caso de Maria que, conquistada e em seguida desprezada por José Pelegrino, se une a mais duas mulheres para "dar tremenda lição no d. Juan". Apesar de a matéria começar com um tom de reprovação a João, que "tão convicto está de que é um Adonis que não cessa de se gabar das aventuras de que tem sido protagonista", o autor não vê a atitude das envolvidas como legítima, chamando-as de "agressoras" e "terríveis". Apesar de ter um sentido diverso do caso anterior, está igualmente carregado de juízos de valor, como se pode constatar no seguinte trecho:

Durante a tarde de ontem, diversos grupos de soldados do Exército e da Marinha andaram em correrias pela rua Senhor dos Passos (...) Quando já ia dissipando o receio de novos conflitos, a conhecida vagabunda e meretriz, moradora a mesma rua n. 99, Áurea Salles de Campos da sua janela começou a proferir obscenidades contra dois soldados do Exército. Intervindo a patrulha de cavalaria, foi desrespeitada pela endiabrada Áurea, pelo que foi presa e ia ser conduzida para a $4^{\text {a }}$. [delegacia] quando intervieram diversos soldados do 1 Batalhão de Artilharia de posição do exército, que a viva força pretendiam soltar a mulher. Estabeleceu-se grande conflito entre as partes, atacando os soldados armados de facas a patrulha de polícia. ${ }^{57}$

Enquanto alguns soldados eram xingados por Áurea, outros a defendiam e, para impedir que fosse presa, enfrentavam os policiais da Brigada Policial. Esses, por sua vez, haviam sido chamados pelo delegado da 4aㅡ circunscrição urbana, com o objetivo de conter o conflito entre praças do Exército e da Marinha. A atuação da mulher acirrava as desavenças já existentes entre aqueles homens. A desqualificação de Áurea, descrita como "conhecida vagabunda e meretriz" e "endiabrada", se estende aos homens que a defendiam. Mas, se os jornalistas eram, em alguma medida, "contaminados" pelos valores expressos nos documentos policiais, é importante destacar que há muitas diferenças entre os relatos das ocorrências e aqueles transcritos nas páginas do jornal. ${ }^{58}$ Nas fontes impressas, havia mais espaço para divagaçóes e mais preocupação em escolher um estilo narrativo que prendesse a atenção do leitor.

Além da preocupação de atrair leitores, essas notícias de crimes, particularmente aquelas envolvendo mulheres, também nos permitem constatar que conselhos em relação à forma como se conduzir não eram dados apenas nos textos, em francês, da elegante Santuzza. Eles estavam disseminados nesses relatos, alguns bastante trágicos, nos quais os comportamentos dos envolvidos eram descritos, comentados e adjetivados. Grande parte das protagonistas desses casos provavelmente não sabia ler e, talvez, seu único interesse pelo jornal fosse a seção de anúncios, em que poderiam encontrar uma ocupação a partir das demandas aí expressas, como "precisa-se de uma criada" ou "precisa-se de uma cozinheira".

Por outro lado, essas mulheres poderiam escutar a leitura dessas notícias de sensação, publicadas em A Imprensa; contra a vontade de seu editor-chefe, mulheres pobres e trabalhadoras poderiam ouvir histórias que despertavam seu interesse, justamente por se identificarem com suas personagens. Por outro lado, esses relatos atraíam, também, aquelas que não se enquadravam em nenhum dos dois extremos mulheres que não sabiam francês, mas que tampouco se aproximavam daquelas que protagonizavam as seçóes policiais -, uma vez que tinham interesse na leitura desses casos, que tratavam de amor e morte, em linguagem de folhetim. 
Se havia conselhos de conduta nas notícias policiais, é possível indagar em que medida os jornalistas que redigiam essas notas estavam conscientes desse papel de "conselheiros" ou "educadores". Bem, essas notícias não eram escritas com esse objetivo, ou seja, não havia, propriamente, uma linha editorial com essa orientação. Porém, a julgar pelas outras seções do jornal, com a publicação de textos escritos por mulheres e colunas a elas dedicadas, podemos supor que havia uma preocupação, ainda que difusa, em relação às leitoras do periódico. É mais difícil, contudo, inferir se essas normas de conduta veiculadas através das notícias chegavam a influenciar a atitude de quem as lia. Na tentativa de reunir indícios sobre as interpretaçôes que esses textos poderiam receber, ${ }^{59}$ é pertinente examinar aquelas notícias em que as mulheres tomavam as rédeas da situação, escapando ao controle dos próprios autores dos textos jornalísticos.

Sob o título "Dois Raptos - praças do $10^{\circ}$ - casa de cômodos", conhecemos a história de duas irmãs que viviam sob proteção do proprietário da loja de armarinhos da Rua Barão de São Felix, n. 32. As moças se apaixonaram por dois praças do $10^{\circ}$ Batalhão de Infantaria que, "impacientes por unirem de uma vez suas almas às das amadas, tramaram imediatamente um rapto, o qual, aceito pelas moças, ficou assentado e preparado para o domingo passado" ${ }^{60}$ Consumada a ação, um dos praças confessou o crime e se prontificou a casar, enquanto o outro não apareceu. A notícia inclui a transcrição de uma carta de amor que havia sido escrita por um dos rapazes.

Como indica um dos subtítulos, a nota também comentava o estado das casas de cômodos, para onde os dois casais haviam se dirigido para concretizar o "rapto". O redator chamava a atenção do chefe de polícia em relação a esses "centros de desmoralização", onde havia gente "da pior espécie e [que] vive numa promiscuidade horrorosa, no meio de uma desordem e dessaceio (sic), que dão a esses prédios um aspecto sinistro e medonho, de verdadeiros antros de vícios e crimes". Mais uma vez, habitaçóes coletivas provisórias - como casas de dormida, casas de cômodos e hospedarias - eram associadas à imoralidade e ao crime. Mas, essas constatações são dirigidas especificamente à autoridade, no sentido de pedir providências. Na narrativa, não pesa sobre as duas irmãs a culpa por terem frequentado esse ambiente, ainda que seu autor deixe claro que o rapto fora "aceito pelas moças".

Parece que o jornalista simplesmente ignorava as moças e suas ações, como se fossem incapazes de escolher, ou como se suas escolhas não tivessem peso algum. Assim, a responsabilidade em relação ao rapto caberia aos praças e, em última instância, à displicência da própria polícia que, segundo o texto, não atuava corretamente em relação às casas de cômodos. Por outro lado, fica registrado que o rapto fora algo consentido, já que as duas haviam se apaixonado. Para moças como elas, o rapto poderia ser visto como uma estratégia para conseguir a permissão para casamentos proibidos pelos seus responsáveis ${ }^{61}$ e, nesse sentido, a forma como o fato foi noticiado, incluindo a publicação de uma carta de amor, confere publicidade ao gesto, neutralizando o que seria um antiexemplo.

No mesmo dia em que essa notícia foi publicada, temos outro caso semelhante em "Paixão Contrariada". Trata-se da história de Maria Rosa Pereira, apaixonada por Manoel José Parente; a família da moça, porém queria que ela se casasse com José Correia Pinto, homem mais velho, "visto ser ele homem trabalhador e possuidor de muitos bens". Parente, então, pediu um despacho ao juiz para que pudesse depositar a moça em uma casa de família a fim de desposá-la e, ainda que a família tentasse impedir, o despacho foi cumprido. ${ }^{62}$ Outro caso pode ser subentendido a partir da publicação, alguns dias mais tarde, de um ofício do chefe de polícia ao delegado da $18^{a} .{ }^{63} \mathrm{O}$ chefe recomendava que o delegado chamasse dona Juliana e sua filha deflorada para depor, já que a mãe era contra o casamento da filha com o ofensor. Tanto o consentimento das filhas, quanto o embargo das mães eram possibilidades de ação que o jornal colocava à mostra e, em algumas situações, em debate.

Como vimos acima, outro aspecto dessas notícias de crimes, não raro sensacionalistas, era o seu emprego para fazer críticas à polícia. Assim, além da moralidade dos envolvidos, o jornalista julgava a moralidade dos próprios policiais. Em notas como "Delegado que espanca mulheres" e "Delegado cobrador", ${ }^{64}$ vemos severas reprovações à postura dessas autoridades. Às vezes, o foco das críticas é, espe- 
cificamente, um indivíduo, como acontece com o 2o Delegado Auxiliar, Geminiano da Franca que, ora é reprovado por proibir duetos nas casas de chope, ora por proteger os café cantantes, "cujo fechamento é exigido pela moral pública". ${ }^{65}$ Mesmo quando a polícia atendia aos "reclamos da imprensa", suas ações poderiam ser alvo de ressalvas:

Nesta coluna, por mais de uma vez, reclamamos providências da polícia para os constantes distúrbios, promovidos pelos conquistadores baratos das caixeiras dos chopps, conhecidas melhor por camareiras. Outros colegas trataram também do assunto. A autoridade da $7^{\mathrm{a}}$. circunscrição não se conservou indiferente aos reclamos da imprensa e ordenou que cessasse a prática de serem tais estabelecimentos servidos por mulheres. (...) Continuaram as camareiras a servir os fregueses do chopps. (...) Não teve duvida o delegado e mandou postar à porta de cada chopp duas praças de polícia, com ordem terminante de não deixarem entrar quem quer que fosse, sem primeiro a ordem ser executada. (...) Fomos dos que mais clamaram contra as camareiras. A polícia tem, porém, outros meios mais convenientes de obrigar os desobedientes a entrarem no bom caminho. Use destes meios a polícia, e terá os aplausos da população. ${ }^{66}$

Se a presença das caixeiras provocava "constantes distúrbios", isso não dava à polícia o direito de coibir o comércio, pois essa seria uma ação ilegal. $\mathrm{Na}$ matéria, o uso da primeira pessoa do plural, indica que não se tratava de uma reclamação de um único jornalista, mas do jornal como um todo. A medida adotada pelo referido delegado foi elogiada, mas não os "meios" para colocá-la em prática. Na verdade, exigir da polícia certas atitudes, desde que os direitos constitucionais fossem observados, sempre foi uma das bandeiras do próprio Rui Barbosa, que fazia duras críticas contra a instituição policial. Em um de seus artigos, dirigindo-se a Campos Salles, ele assevera:

Abra s. ex. A Polícia de Yves Guyot, e logo às primeiras páginas se lhe deparará este ensinamento magistral: "uma mulher é prostituta. Trata-se de saber se, por isso, já não existem, para ela, as leis. Ouço às vezes queixas das reclamantes, que me vem dizer: 'a polícia prendeu-me, e maltratou-me. Mas sou mulher honesta'. É o que não importa. A polícia, a não haver delito, não tem mais direito de maltratar a uma rameira que a uma senhora. Nosso direito político declara a lei igual para todos: não estabelece uma para as mulheres casadas, outra para as cortesãs". Eis a doutrina, a verdade, o evangelho. Eis o nosso direito, a nossa constituição, a nossa legalidade. ${ }^{67}$

O artigo tinha sido escrito por ocasião da morte da meretriz Ida Maria Salles, presa injustamente, simplesmente por estar à janela da casa onde morava, à Rua Sete de Setembro. Detida com outras mulheres, morreu por asfixia no xadrez da $4^{\mathrm{a}}$ circunscrição. $\mathrm{O}$ caso se diferencia das notícias policiais justamente por abarcar um aspecto maior: o desrespeito da polícia à própria Constituição. Isto confere outra dimensão ao caso, permitindo que Rui Barbosa dirija sua reprovação ao próprio presidente da República.

No artigo seguinte sobre esse mesmo tema, "Por onde rebenta a corda", ${ }^{8}$ Rui acusava os policiais daquela delegacia de terem prendido Ida Maria por vingança, por ela não pagar as "taxas" que eles haviam imposto às "infelizes de sua classe". Ou seja, para ele, a mulher era uma vítima da polícia em vários aspectos, do suborno à perseguição física. Em outro artigo sobre o tema, "O Siso à Toleima", ${ }^{69}$ respondia às acusações que recebera em outros órgãos da imprensa:

Que sustentávamos nós em 1899? Que as orgias do prostíbulo se devem celebrar a venezianas cerradas. Pugnando por esse rudimento de polícia e moralidade, não criávamos um regime de exceção e perseguição contra as messalinas. Pedíamos simplesmente a aplicação a elas das mesmas normas de decoro, a que são obrigados os casais. ${ }^{70}$

Observe-se a referência a outro artigo, "Ponéia", de sua autoria, publicado em 12 de dezembro de 1899, e reproduzido nessa ocasião. Com isso, Rui retomava a ideia de que a defesa da moralidade deveria ocorrer dentro da lei, não podendo pressupor nenhuma forma de "exceção e perseguição". O seu envolvimento no caso de Ida Maria não significava que defendia os interesses das prostitutas, mas que militava pelo cumprimento da lei e da constituição. 


\section{De $A$ Imprensa ao Correio}

$\mathrm{Na}$ Ata da Assembleia de Instalação e Estatutos da Sociedade Anônima A Imprensa, publicada no Diário Oficial de 29 de outubro de 1898, o nome de Edmundo Bittencourt figurava como um dos membros do Conselho Fiscal. ${ }^{71}$ Natural de Santa Maria, no Rio Grande do Sul, esse homem fizera seus primeiros estudos em Porto Alegre, vindo depois para São Paulo e, em seguida, para o Rio de Janeiro, onde começara a advogar com Rui Barbosa e Sancho de Barros Pimentel. ${ }^{72}$ Por ocasião da primeira crise de $A$ Imprensa, que determinou seu fechamento por três meses, no ano de 1900, Bittencourt escreveu uma carta a Carlos Viana Bandeira, expressando seu desejo de adquirir a folha:

(...) o nosso Mestre não pode deixar agora o seu posto. Podiam tomar por uma deserção, uma conveniência (...) Mas, há uma solução, e é a que eu mais almejo: o Mestre continua a escrever com a assinatura dele (....) Era meu pensamento fazer do jornal um órgão de colaboração, à feição do Matin e do Figaro. Artigos assinados, e uma só limitação à liberdade dos colaboradores, uma coisa para nós sagrada: - o nome do fundador da folha. A redação teria o seu programa no passado do jornal, que havia de ser guardado, custasse o que custasse, como uma herança sagrada. Era isto o que eu pensava, porque, digo-te com franqueza, temo que o Mestre não tenha confiança em mim e se recusasse a continuar na folha. ${ }^{73}$

No auge de "A Pavorosa" e do caso Andrade Figueiredo, Bittencourt temia que o fim da publicação do jornal fosse interpretado como uma "deserção" de Rui Barbosa, ao qual se referia como "Mestre". Além da preocupação em conservar a imagem de Rui, ele também se manifestava em relação à folha, para a qual gostaria de dar uma nova feição. Sua proposta era de que o jornal mudasse de propriedade e de características, mas mantivesse o mesmo fundador, "uma coisa para nós sagrada". Se sua proposta tivesse sido aceita, Bittencourt assumiria $A$ Imprensa, ao invés de abrir um novo jornal. Porém, como vimos, essas intenções foram frustradas, já que coube a Ulisses Soares Brandão, colega de Rui Barbosa, a reorganização da empresa naquele momento.

Nesse trecho da carta de Bittencourt, há a menção ao modelo francês de jornal, o que contrariava o padrão seguido pelo periódico até então. Ele não fazia referência a ilustrações, algo que havia sido defendido por Carlos Bandeira Viana anteriormente, mas se batia pela variedade de colaboradores. Por ocasião da fundação do Correio da Manhãa, em junho de 1901, a ideia de "fazer do jornal um órgão de colaboração" foi posta em prática. Assim, as colunas de honra do novo periódico seriam escritas pelos mais diversos colaboradores, mesmo que tivessem divergências irreconciliáveis: "desde o jurisconsulto ao alto funcionário de vida inteiramente alheia às lutas partidárias; do monarquista de antiga fé inquebrantável até o republicano mais instigante e apaixonado, e, ao lado deles, o fino e puro artista" ${ }^{74}$ A nova folha não se organizava, portanto, em torno dos artigos e da figura de Rui Barbosa, mas mantinha a mesma militância política no que tange à revisão constitucional. No programa do Correio, Bittencourt afirmava, entre insinuaçôes e ironias, que: "há no periodismo de hoje um como constrangimento diante da verdade e, diante dos fatos do governo, um temor que não se justifica, porque a justiça manda que se diga que o governo do honrado sr. dr. Campos Salles tem sido paternal e bom para a nossa imprensa."75

Segundo o autor, o governo pagava aos jornais para que eles omitissem ou atenuassem as notícias que lhe fossem desfavoráveis. Com isso, o novo proprietário não só traçava um panorama extremamente negativo da imprensa da época, como marcava sua oposição em relação ao governo de Campos Salles. Como vimos, críticas ao "periodismo" e ao governo federal haviam sido recorrentes em toda a trajetória de $A$ Imprensa, principalmente nas intervenções de Rui Barbosa. Então, desde sua fundação, o Correio da Manhã se apresentou como um jornal de oposição ao governo Campos Salles. Um dos motivos que justificava essa postura era a intervenção do então presidente na imprensa, em relação à qual a nova folha queria destacar-se. Mas as críticas também constituíam, segundo Edmundo Bittencourt, a expressão da própria "oposição popular" a esse governo. ${ }^{76}$ 
Por defender e expressar os interesses populares, o jornal também se pronunciou contra a candidatura de Rodrigues Alves, "imposta" pelo antecessor, destacando que "a nação não elegeu a s. ex., e por uma razão muito simples: ela não tem o direito de votar." "77 Por outro lado, admitia que o novo presidente inspirava confiança, apresentando "incontestável superioridade" sobre Campos Salles. Porém, um ano após a posse de Rodrigues Alves, Gil Vidal, pseudônimo do coeditor Leão Velloso Filho, diagnosticava que "governo algum decaiu tanto da estima pública em tão pouco tempo" ${ }^{78}$ A oposição do jornal a Campos Salles e a Rodrigues Alves não indicava uma questão circunstancial, relacionada, apenas, aos erros administrativos e políticos desses homens. Ao contrário, esse posicionamento era o reflexo das investidas do jornal contra a própria "Política dos Governadores", ou seja, a intervenção nefasta das oligarquias rurais na política nacional só poderia ser combatida por meio da revisão da Constituição.

Por isso, desde o início, a folha adotou uma postura revisionista, no sentido de limitar a ação dos estados e, consequentemente, das oligarquias. A revisão da Constituição também era apontada como a condição necessária para empreender outras reformas, como a eleitoral e a judiciária. A primeira Constituição Republicana, aprovada em 24 de fevereiro de 1891, inspirava-se na organização federativa dos Estados Unidos. Porém, a autonomia dos estados membros da federação havia sido objeto de debates intensos na constituinte, com recorrentes enfrentamentos entre unionistas, entre os quais se destacava o próprio Rui Barbosa, e federalistas, isto é, partidários de estados com ampla autonomia política. ${ }^{79}$ No 12을 Aniversário da Constituição, "deslembrado entre os folguedos do Carnaval", Gil Vidal ponderava:

Mas, ainda que o povo não estivesse engolfado nas loucas alegrias que precedem a quaresma, não comemoraria festivamente os anos da Constituição que, mal grado as excelentes intenções dos constituintes, não obstante a sabedoria de muitas de suas disposiçōes, deu azo ao que vemos figurando de federação, mas que, na realidade, é a liga das oligarquias que antepõe os seus interesses aos da Nação, e por toda a parte oprimem a liberdade dos brasileiros. (...) Se vive assim desprotegido o cidadão, convertida a própria justiça em instrumento de domínio, o governo nacional sente-se despojado de força precisa para, no desempenho de sua elevada missão, assegurar a defesa externa e resguardar a união e a integridade da pátria. ${ }^{80}$

$\mathrm{Na}$ visão do autor, a Constituição não parecia fazer sentido algum para a população carioca naqueles primeiros anos do século XX, situação que seria revertida com a verdadeira garantia de direitos através da revisão constitucional. Essa posição favorável à revisão da Constituição também era recorrentemente difundida no jornal $A$ Imprensa, inclusive no próprio programa do jornal, redigido por Rui Barbosa. Embora não fosse mencionada no artigo-programa do Correio da Manhãa, essa questão foi o mote de vários artigos assinados por Edmundo Bittencourt, ao longo dos primeiros anos de publicação. Mas, se Rui Barbosa e Edmundo Bittencourt compartilhavam alguns posicionamentos políticos, é importante destacar que empregavam linguagens bastante distintas em seus textos.

Enquanto Rui prezava uma discussão fundamentada em argumentos sólidos e exemplos históricos, Edmundo lançava críticas e reivindicações de forma mais direta e contundente. Um exemplo significativo desse procedimento foi a própria campanha das carnes verdes com que iniciamos este percurso. No primeiro artigo do Correio sobre o tema, eram apresentadas três denúncias: o preço elevado da carne; sua péssima qualidade; e a existência de um inquérito interrompido por questões políticas. Todos esses problemas decorriam do fato de a empresa de carnes verdes pagar suborno aos funcionários municipais.

O primeiro artigo de uma série de denúncias chamava atenção não só pelo seu conteúdo bombástico, mas pela forma como havia sido redigido. Bittencourt escrevia como se estivesse conversando com o público: narrava uma história sem especificar quando ela havia ocorrido e como chegara ao seu conhecimento. Mais que isso, ele criava cenas e diálogos entre os personagens envolvidos. Eis, na versão de Bittencourt, a reação do presidente Campos Salles, quando o prefeito Coelho Rodrigues lhe anuncia a intenção de demitir o dr. Torres Cotrim, um dos funcionários que teria recebido suborno da empresa:

Mal s. ex. acabava de anunciar ao chefe do estado a deliberação honesta que tomara, este punha as mãos na cabeça, e suplicava-lhe aterrado: 
“- Pelo amor de Deus, não faça semelhante coisa!... Este homem é cunhado do dr. Nuno de Andrade, diretor geral da higiene... O seu ato vai trazer-me complicaçôes muito sérias. Não, nunca! Não me demita este homem!...."

O texto explora a fronteira entre fato e ficção para prender a atenção do leitor. ${ }^{82}$ Parece que a intenção desse primeiro artigo era, efetivamente, causar indignação, mais do que informar, ou explicar o que havia acontecido. Isso seria feito aos poucos, em cada um dos textos subsequentes, como capítulos de uma novela. Toda a campanha foi empreendida pela pena de Bittencourt, que representava o posicionamento do jornal em relação àquele problema. Em A Imprensa, Rui Barbosa ocupara o papel de principal "porta-voz" do periódico, mas seus textos eram muito mais elaborados, com comparaçóes entre diferentes países e citaçōes de autores estrangeiros. ${ }^{83}$

Além das limitações pessoais, pois Bittencourt certamente não contava com uma formação tão vasta e diversificada quanto a de seu "Mestre", podemos observar estratégias diferenciadas para se dirigir aos leitores. Na campanha das carnes verdes, temos a impressão de que a linguagem das notícias policiais invadia os artigos. Recheados de denúncias, ofensas, descriçóes de cenas e críticas às autoridades, esses textos poderiam ser lidos - e facilmente compreendidos - pelos mais variados leitores.

Além disso, ao lado das análises sofisticadas dos colaboradores da coluna de honra e dos editorais assinados por Gil Vidal, o Correio da Manhã apresentava uma coluna dedicada à "classe acadêmica" e outra "para falar de coisas militares e fazer ecoar as vozes dos quartéis". ${ }^{84} \mathrm{Na}$ seção "Vida Operária", era possível a publicação de cartas enviadas por leitores que se identificavam como a "classe operária", 85 concedendo, portanto, aos trabalhadores, a possibilidade de um espaço para a expressão. Seguindo a tendência de outras folhas, alguns anos após a sua fundação, o Correio da Manhã abria uma seção para dar voz aos moradores dos subúrbios da cidade do Rio de Janeiro. ${ }^{86} \mathrm{O}$ jornal apresentava-se, assim, como a reunião de espaços e vozes plurais, na tentativa de congregar leitores oriundos de diferentes classes sociais.

Então, enquanto em $A$ Imprensa parecia haver uma tensão e mesmo um descompasso entre os textos eruditos do editor-chefe e o estilo das notícias policiais, no Correio essa linguagem era empregada pelo diretor, em seus próprios artigos, nos momentos em que falava em nome da opinião do jornal como um todo. Em relação à composição do jornal como um todo, Rui Barbosa parecia condenar o "sensacionalismo" e o "culto do escândalo", na mesma medida em que Bittencourt buscava incentivá-lo. Não surpreende, portanto, o fato de o Correio se tornar famoso, entre os contemporâneos, por suas extensas e detalhadas notícias de crime, cujo teor foi satirizado no romance Recordaçôes do Escrivão Isaías Caminha, de Lima Barreto. ${ }^{87}$

Tendo em vista essas considerações, podemos concluir que $A$ Imprensa e o Correio da Manhã não representam um projeto único, o que se traduz na própria trajetória que tiveram. Enquanto $A$ Imprensa enfrentou inúmeros momentos de crise financeira e não durou mais que três anos, o Correio se estruturaria, em pouco tempo, como uma empresa sólida e amplamente reconhecida, capaz de atravessar décadas a fio. Além das questões empresariais, o sucesso da nova folha também deve ser atribuído ao seu conteúdo e aos recursos mobilizados para atrair e manter leitores. Se, em aspectos políticos, as duas folhas se assemelhavam, engajando-se nas mesmas disputas políticas, é possível dizer que Rui Barbosa e Edmundo Bittencourt afastavam-se, no que tange à forma de entender o jornalismo e produzir um periódico, nas armas que mobilizavam, enfim, nas disputas por leitores.

\section{Notas}

${ }^{1}$ Cidade do Rio, 13/07/1901, página 1.

${ }^{2}$ Ver Cidade do Rio, 08/07/1901 (“D. Quixotino") e Cidade do Rio, 16/07/1901 (“Bacharel Epaminondas”). A referência ao personagem de Cervantes, ingênuo e sonhador, era uma forma de desqualificar o caricaturado. Epaminondas se refere, provavelmente, ao general e estadista beócio (418-362 a.C.) que se ligou a Tebas e enfrentou diferentes cidades para manter sua independência. 
${ }^{3}$ Sobre esse assunto, ver LIMA, Herman. Rui e a caricatura. Rio de Janeiro, Olímpica, 1950.

${ }^{4}$ Sobre esse caso e sua repercussão posterior, ver MAGALHĀES JR., Raimundo. Rui e o caso das carnes verdes. In: Rui, o homem e o mito. Rio de Janeiro, Civilização Brasileira, 1965.

${ }^{5}$ Sobre essa campanha e suas repercussōes ver GARZONI, Lerice de Castro. "Nós, em nome do povo, cuja causa defendemos": o Correio da Manhã e a campanha contra as carnes verdes (1901). In: XXV Simpósio Nacional de História: História e Ética, 2009, Fortaleza. Anais do XXV Simpósio Nacional de História, 2009.

${ }^{6}$ Ver, entre outros, artigo "Amônia a um bêbado" de José do Patrocínio, publicado como editorial do Correio do Rio, em 15/07/1901 e na seção "Publicações a pedidos" do Jornal do Commercio de 16/07/1901.

${ }^{7}$ O prestígio de Rui Barbosa decorria, entre outros motivos, de sua intensa participação na política imperial. Ao fim de seu segundo mandato parlamentar, em 1884, ele recebeu o título de "conselheiro", reconhecimento oficial pelos serviços prestados ao Império. Pouco tempo depois, se engajou na campanha abolicionista e republicana, tendo ocupado o cargo de ministro da Fazenda no Governo Provisório. Data desse período, compreendido entre os anos de 1889 e 1891, a iniciativa de queimar os documentos relativos à escravidão e o fracasso do encilhamento. No governo de Floriano Peixoto, Rui Barbosa se estabeleceu como oposição ao governo, sendo obrigado a se exilar na Inglaterra entre 1893 e 1895 . Nos primeiros governos civis, Rui manteve uma posição de crítica, principalmente a Campos Salles. Sobre a vida de Rui, ver GONÇALVES, João Felipe. Rui Barbosa: pondo as idéias no lugar. Rio de Janeiro: Editora FGV, 2000.

${ }^{8}$ A correspondência está no fundo "Edmundo Bittencourt" (CR 208/1) do arquivo da Casa de Rui Barbosa. O fundo é composto por 66 cartas, cartões e telegramas trocadas entre 1896 e 1921.

${ }^{9} \mathrm{Na}$ sua juventude, Rui Barbosa colaborou para diversos jornais em São Paulo e foi redator do Diário da Bahia. No Rio de Janeiro, além de inúmeras colaboraçôes esparsas e artigos em seçōes pagas, teve uma breve participação como redator-chefe de O Paiz em 1884, assumiu a direção do Diário de Notícias em 1889 e a do Jornal do Brasil em 1893. Durante o exílio, entre 1893 e 1895, colaborou para o Jornal do Commercio, com a série de artigos "Cartas de Inglaterra". Ver GONÇALVES, João Felipe. op. cit. e MAGALHĀES Jr., R. "Rui e o jornalismo", em Rui, o homem e o mito, op. cit., p.112-136.

${ }^{10}$ LACOMBE, Américo Jacobina. À sombra de Rui Barbosa. São Paulo: Editora Nacional, 1978, p. 70 e MAGALHÃES Jr., R. "Rui e o jornalismo" em op. cit., p. 119.

${ }^{11}$ Gazeta de Notícias, 07/10/1898.

${ }^{12}$ Jornal do Commercio, 06/10/1898.

${ }^{13}$ Apud VIANA FILHO, Luis. A vida de Rui Barbosa. São Paulo: Nacional, 1949, p. 275.

${ }^{14}$ Ver, entre outros, editoriais de A Imprensa intitulados "Agora eu" e "Como quiserem" dos dias 9 e 13 de fevereiro de 1900. Rui Barbosa se defende das acusações feitas por José Carlos Rodrigues no Jornal do Commercio sobre o caso da Companhia de São Cristóvão.

${ }^{15}$ A Imprensa, "Palavras de um descrente", 10/03/1900.

${ }^{16}$ Sobre a característica de Rui apresentar autobiografias para se defender, ver GONÇALVES, João Felipe, op. cit., p. 97.

${ }^{17}$ Segundo Lacombe, "apesar do entusiasmo que despertou o reaparecimento de Rui Barbosa como jornalista, e do esforço desenvolvido pela administração, o relatório da sociedade em 1899 não consignava grandes vantagens. Em princípios de 1900, porém, a situação se agravou.” LACOMBE, Américo Jacobina, op. cit., p. 73.

${ }^{18}$ Idem, p. 73-74.

${ }^{19}$ Em nota de $A$ Imprensa, de 07/08/1900, foi transcrita a saudação do Cidade do Rio: “(...) temos estado em inteiro antagonismo de ideias e de sentir com ele [Rui Barbosa], teremos de combate-lo amanhã, já mesmo. Mas tratou-se, trata-se e há de tratar-se de um grande espírito, embora um adversário, a quem os cumprimentos de estilo devem ser feitos com a correção da pragmática, porque é ele um potência no jornalismo (...)”. Sobre os ataques da Cidade do Rio a A Imprensa, ver LACOMBE, Américo Jacobina, op. cit., p. 93-4.

${ }^{20}$ A Imprensa, 06/08/1900.

${ }^{21}$ GONÇALVES, João Felipe, op. cit., p. 62.

${ }^{22}$ A Imprensa, "Um caso pudendo - Vênus no Tesouro", 10/09/1900.

${ }^{23}$ A Imprensa, "Muitos obrigados", 30/11/1900.

${ }^{24}$ A Imprensa, "Rui Barbosa", 08/03/1901.

${ }^{25}$ A Imprensa, "Continuando", 01/08/1900.

${ }^{26}$ A Imprensa, "Duas Imprensas", 16/10/1900.

${ }^{27}$ Em 01/01/1899, A Imprensa anunciava que seus assinantes ganhariam um seguro Sul América gratuito. Em 06/01/1900, informava que os assinantes de seis meses ganhariam um romance e os de um ano, "além do exemplar, uma fosforeira, um cinzeiro japonês, um charuto, uma carteira, um volume de O problema naval, de Arthur Dias (prefaciado por Rui Barbosa), ou O Guarani, de José de Alencar”. 
${ }^{28}$ Agar Eva Infanzón y Canel (1857-1924) nasceu nas Astúrias, mas morou durante muito tempo na América Latina, em países como Argentina, Chile e Cuba. Ao lado do marido, o escritor Perillán Buxó, dirigiu diversos periódicos. Após ficar viúva (1899) passou a viver da literatura, colaborando em diversos periódicos e fazendo conferências por países latinos. Conservadora, ela apóia a Espanha durante a guerra de independência. Suas palestras versam, sobretudo, sobre a importância do sentimento hispanoamericano. KENMOGNE, Jean. Una escritora asturiana en América: Eva Canel. Cuadernos Hispanoamericanos, dezembro de 1995.

${ }^{29}$ A Imprensa, "Eva Canel - combate ao feminismo - conferência de ontem”, 14/01/1900.

${ }^{30}$ A Imprensa, "Eva Canel”, 23/01/1900.

${ }^{31}$ A Imprensa, "As Brasileiras", 23/02/1900.

32 Júlia Lopes de Almeida (1862-1934) foi jornalista e autora de livros de sucesso entre o final do século XIX e a primeira metade dos anos 1930. SOIHET, Rachel Comparando escritos: Júlia Lopes de Almeida e Carmem Dolores. Caderno Espaço Feminino, v. 9, n. 10/11, 2001/2002, p. 85-107.

${ }^{33}$ A Imprensa, "Carteira de um jornalista”, 02/02/1900.

${ }^{34}$ Idem.

${ }^{35}$ A Imprensa, "Carteira de um jornalista”, 11/02/1900.

${ }^{36}$ A Imprensa, "Carteira de um jornalista”, 18/02/1900.

${ }^{37}$ A Imprensa, "Subscrição", 18/01/1899. Como lembra Cristiana Schettini, os nomes de algumas senhoras também eram publicados nas votaçōes que os jornais diários faziam, nas últimas décadas do século XIX, para eleger os melhores carros e sociedades após o carnaval. Ver SCHETTINI, Cristiana. Os senhores da alegria: a presença das mulheres nas Grandes Sociedades carnavalescas cariocas em fins do século XIX. In: CUNHA, Maria Clementina Perereira (Org.). Carnavais e outras frestas: ensaios de história social da cultura. Campinas: Editora da Unicamp, 2002, p. 317.

${ }^{38}$ Entre outras, podemos citar uma nota do dia 07/12/1900 anunciando que "a sra. D. Rosina Del Vecchio, diretora do Colégio Sul-Americano, dirigiu-nos amável convite para assistir à festa do encerramento das aulas daquele estabelecimento”. No dia 07/03/1901, a folha informava que "deve partir, por estes dias, para a Europa a nossa talentosa compatriota, senhorita Julieta França (...)".

39 "Petit bleu" era a forma de designar os telegramas, que eram transmitidos em um papel azul. Sobre a presença de cartas fictícias no jornal, Pierrette Lebrun-Pezerat se questiona: "mais pourquoi ce recours rédactionnel aux lettres fictives qui constiutuent parfois une part importante de la matière des journaux? Pour produire un effet de vérité (...) Pour rompre avace les formes traditionnelles des articles d'information, l'énoncé souvent ennuyex des nouvelles, grâce au truchement du 'je', un peu de vie, une possibilité d'identification et, éventuallement, da la polemique? Pour toutes ces raisons sans doute, et peutêtre d'autres encore». Esses questionamentos nos ajudam a refletir sobre as escolhas das colaboradoras ou colaboradores de "Petits Blues", mesmo se considerarmos que se trata de uma seção específica, ou seja, não diretamente ligada à redação do jornal. Ver LEBUN-PEZERAT, Pierette. La lettre au journal: les employés des Postes comme épistoliers. In : CHARTIER, Roger (Org.). La correspondance: les usages de la letrre au XIXe. Siècle. Paris: Arthème Fauard, 1991, p. 428.

${ }^{40}$ Sobre Santuzza, ver "Petits Blues" de 04/03/1900 e sobre Suzette, o de 23/04/1900.

${ }^{41}$ Ver, respectivamente, "Petits Blues", 10/03/1900 e "Sombrinhas", 12/03/1900.

42 Analisei essa série em "As cartas de Santuzza: uma análise da seção 'Petits Bleus' do jornal A Imprensa (Rio de Janeiro, 1900)”, apresentado no Seminário Internacional Fazendo Gênero 9, Florianópolis, UFSC, 2010.

${ }^{43}$ A Imprensa, "Croquis Politiques", 12/09/1900.

${ }^{44}$ Essa questão da interlocução feminina no trato de assuntos políticos na imprensa é bastante interessante e demanda maiores investigações. Entre 1892 e 1893, Coelho Netto publicou a série intitulada "Bilhetes Postais” no jornal O Paiz. Em muitas crônicas dirigia-se a mulheres, o que dá a impressão de literatura leve e descompromissada. Porém, em outras tantas crônicas, fazia críticas veladas ao governo de Floriano Peixoto, que naquele momento promovia a perseguição de muitos dos seus amigos literatos. À primeira vista, a interlocução feminina aparece como uma fachada para tratar de outras questôes, mais sérias e importantes. Seria essa a mesma motivação do autor da seção "Petits mots du matin"? No final de 1898, a Gazeta de Notícias traz uma seção, de publicação irregular, intitulada "Lettres d'une créole” em que a narradora Dora escreve a diferentes políticos, comentando e criticando suas ações. Autor e destinatário se invertem, mas a intenção de falar de política se mantém. No dia 06/10/1898, por exemplo, ela se dirige ao deputado Nilo Peçanha. Sobre "Bilhetes Postais", ver NETTO, Coelho. Bilhetes postais. Organizado por Ana Carolina Feracin da Silva, Campinas: Mercado das Letras, 2002.

${ }^{45}$ A Imprensa, "Petits mots du matin", 10/01/1901.

${ }^{46}$ BANDEIRA, Carlos Viana. Lado a lado com Rui (1876-1923). Rio de Janeiro: Ministério da Educação e Cultura, Casa de Rui Barbosa, 1960 apud MAGALHĀES Jr, Raimundo, op. cit., p.129.

${ }^{47}$ Em 11/04/1900, vemos o desenho de um confessionário onde uma senhora fala e o padre boceja. Na legenda: "Que sensaboria!... Coitadinhas!... Ao confessionário, são tão pobres de imaginação!...”. Em 16/04/1900, sob subtítulo "Os impacien- 
tes", foi retratada uma situação que se passara em um restaurante, onde uma senhora brigava com um homem: "E agora, seu grandíssimo devasso? Nega ainda? Ah! É para isto que está a dever dois meses no senhorio? É para isto que despediu a cozinheira e obriga a minha filha a passar o dia no fogão? É para isso que quer que eu me mate a dar-lhe 'lustre' nos colarinhos?" Enquanto isso, uma jovem cobria o rosto e chorava e, no fundo, um garçom presenciava a cena assustado.

${ }^{48}$ A Imprensa, "Projetos e Esperanças", 05/10/1898 apud O País; "A Imprensa”, 06/10/1898.

${ }^{49}$ A Imprensa, "Suplício Inquisitorial - A fogo de petróleo - A impunidade", 03/01/1899.

${ }^{50} \mathrm{Idem}$.

${ }^{51} \mathrm{Idem}$.

${ }^{52}$ Ver, entre outros, "Cáftens" de 09/08/1900, "Mau Marido" de 06/09/1900 e "Amor e Sangue" de 11/02/1901.

${ }^{53}$ Para outro exemplo desse tipo, em que a mulher é responsabilizada pelo comportamento agressivo do companheiro, ver "Tragédia - Traiu-me, Matei-a!" de 10/03/1900.

${ }^{54}$ A Imprensa, "Mulher para dois", 10/01/1900.

${ }^{55}$ Sobre esses conflitos, particularmente no policiamento da prostituição, ver SCHETTINI, Cristiana. Que tenhas teu corpo: uma história social da prostituição no Rio de Janeiro das primeiras décadas republicanas. Rio de Janeiro: Arquivo Nacional, 2006.

${ }^{56}$ A Imprensa, "Mulheres diabólicas - A Faca e Pau”, 19/04/1900.

${ }^{57}$ A Imprensa, "Correrias - Praças do Exército e da Marinha - Morte e Ferimentos", 23/04/1900.

${ }^{58}$ Sobre essa questão, ver GARZONI, Lerice de Castro. Raparigas e meganhas em Santana (Rio de Janeiro, 1905). In: AZEVEDO, Elciene; CANO, Jefferson; CUNHA, Maria Clementina Pereira; CHALHOUB, Sidney. (Orgs.). Trabalhadores na cidade. Cotidiano e cultura no Rio de Janeiro e em São Paulo, séculos XIX e XX. Campinas SP: Editora da Unicamp, 2009, p. 157-187.

${ }^{59}$ Como lembra Marcia Abreu, "a leitura é uma prática criativa e inventiva (o sentido desejado pelo autor não se inscreve de maneira direta no leitor), resultante do encontro das maneiras de ler e dos protocolos de leitura inscritos no texto". CHARTIER, Roger. Formas e sentido: cultura escrita entre distinção e apropriação. Campinas: Mercado das Letras, 2003, p. 11.

${ }^{60}$ A Imprensa, "Dois Raptos - Praças do 10o - Casas de Cômodos", 18/01/1898, grifo meu.

${ }^{61}$ Sobre o rapto como estratégia, ver ABREU, Martha. Meninas perdidas: os populares e o cotidiano do amor na Belle Époque. Rio de Janeiro: Paz e Terra, 1989.

${ }^{62}$ A Imprensa, "Paixão Contrariada", 18/01/1898.

${ }^{63}$ A Imprensa, "Ofícios do dr. Chefe de Polícia", 22/01/1898.

${ }^{64}$ A Imprensa, 07/01/1900 e 17/10/1900, respectivamente.

${ }^{65}$ A Imprensa, "Polícia Pudica - Geminiano, o casto - Moralidade no chopp", 18/03/1900 e "Polícia Inútil - O delegado da $4^{a}$ - Incompetente", 25/11/1900.

${ }^{66}$ A Imprensa, "Os chopps", 04/12/1899.

${ }^{67}$ A Imprensa, "Sólon, Carlos Magno e Eneas", 21/12/1900.

${ }^{68}$ A Imprensa, "Por onde rebenta a corda", 22/12/1900.

${ }^{69}$ A Imprensa, "O Siso à Toleima", 24/12/1900.

${ }^{70} \mathrm{Idem}$.

${ }^{71}$ LACOMBE, Américo Jacobina, op. cit., p. 72.

${ }^{72}$ SODRÉ, Nelson Werneck. História da imprensa no Brasil. Rio de Janeiro: Mauad, 1999 [1966], p. 287.

${ }^{73}$ Carta de Edmundo Bittencourt a Carlos Viana Bandeira em março de 1900, apud LACOMBE, Américo Jacobina, op. cit., p. 73-4.

${ }^{74}$ Correio da Manhã, "Correio da Manhâ", 15/06/1901.

${ }^{75}$ Idem.

${ }^{76}$ Correio da Manhã, "Oposição Popular" de Edmundo Bittencourt, 17/07/1902, p. 1.

${ }_{77}$ Correio da Manhã, "Manifesto Inaugural" de Edmundo Bittencourt, 16/11/1902, p. 1.

${ }^{78}$ Correio da Manhā, "Avenida" de Edmundo Bittencourt, 04/11/1903, p. 1.

${ }^{79}$ Leite, Fábio Carvalho. 1891: a construção da matriz politico institucional da República no Brasil. Rio de Janeiro, Dissertação de Mestrado, Departamento de Direito, Pontifícia Universidade Católica do Rio de Janeiro, 2003, p. 47-67.

${ }^{80}$ Correio da Manhä, "Constituição" de Gil Vidal, 24/02/1903, p. 1.

${ }^{81}$ Correio da Manhã, 01/07/1901, p. 1. 


\footnotetext{
${ }^{82}$ Sobre essa questão ver, entre outros, GOMES, Ana Porto. Crime em letra de forma: sangue, gatunagem e um misterioso esqueleto na imprensa do prelúdio republicano. Dissertação de mestrado apresentada ao Programa de Pós-graduação em História Social da UNICAMP. Campinas, 2003.

${ }^{83}$ Veja as campanhas, mencionadas ao longo do presente texto, empreendidas contra os monopólios em janeiro de 1899 e contra o projeto do divórcio em agosto de 1900. Mesmo no caso de Ida Maria, apesar de fazer denúncias e se dirigir especificamente ao presidente da república, Rui não abre mão das citações que denotam sua erudição.

${ }^{84}$ Ver, respectivamente, Correio da Manhã, "Vida Acadêmica", 22/06/1901 e "Correio da Caserna", 11/07/1901.

${ }^{85}$ Correio da Manhã, "Vida Operária”, 23/06/1902 e 24/06/1902.

${ }^{86}$ Correio da Manhã, "Pelos subúrbios”, 04/02/1904.

${ }^{87}$ BARRETO, Lima. Recordaçôes do escrivão Isaías Caminha. Rio de Janeiro: Editora Ática, 1995 [1909]. No romance, jornal aparece com o nome fictício de $O$ Globo.
}

\section{Fontes e referências bibliográficas}

Jornais A Imprensa, Cidade do Rio, Correio da Manhã, Jornal do Commercio, O Paiz, Jornal do Brasil, Gazeta de Notícias (1890-1901)

BARRETO, Lima. Recordações do escrivão Isaias Caminha. Rio de Janeiro: Editora Ática, 1995 [1909].

NETTO, Coelho. Bilhetes postais. Organizado por Ana Carolina Feracin da Silva, Campinas: Mercado das Letras, 2002.

ABREU, Martha. Meninas perdidas: os populares e o cotidiano do amor na Belle Époque. Rio de Janeiro: Paz e Terra, 1989.

CHARTIER, Roger. Formas e sentido: cultura escrita entre distinção e apropriação. Campinas: Mercado das Letras, 2003.

GARZONI, Lerice de Castro. Raparigas e meganhas em Santana (Rio de Janeiro, 1905). In: AZEVEDO, Elciene; CANO, Jefferson; CUNHA, Maria Clementina Pereira; CHALHOUB, Sidney (Orgs.). Trabalhadores na cidade. Cotidiano e cultura no Rio de Janeiro e em São Paulo, séculos XIX e XX. Campinas SP: Editora da Unicamp, 2009, p. 157-187.

. "Nós, em nome do povo, cuja causa defendemos": o Correio da Manhã e a campanha contra as carnes verdes (1901)". In: XXV Simpósio Nacional de História: História e Ética, 2009, Fortaleza. Anais do XXV Simpósio Nacional de História, 2009.

GOMES, Ana Porto. Crime em letra de forma: sangue, gatunagem e um misterioso esqueleto na imprensa do prelúdio republicano. Dissertação de mestrado apresentada ao Programa de Pós-graduação em História Social da UNICAMP. Campinas, 2003.

GONÇALVES, João Felipe. Rui Barbosa: pondo as idéias no lugar. Rio de Janeiro: Editora FGV, 2000.

KENMOGNE, Jean. Una escritora asturiana en América: Eva Canel. Cuadernos Hispanoamericanos, n. 546, p. 45-61, dezembro de 1995.

LACOMBE, Américo Jacobina. À sombra de Rui Barbosa. São Paulo: Editora Nacional, 1978.

LEBUN-PEZERAT, Pierette. La lettre au journal: les employés des Postes comme épistoliers. In: CHARTIER, Roger (Org.). La correspondance: les usages de la letrre au XIXe. Siècle. Paris: Arthème Fauard, 1991, p. 428.

LIMA, Herman. Rui e a caricatura. Rio de Janeiro: Olímpica, 1950.

MAGALHÃES JR., Raimundo. Rui, o homem e o mito. Rio de Janeiro, Civilização Brasileira, 1965.

SCHETTINI, Cristiana. Que tenhas teu corpo: uma história social da prostituição no Rio de Janeiro das primeiras décadas republicanas. Rio de Janeiro: Arquivo Nacional, 2006.

. Os senhores da alegria: a presença das mulheres nas Grandes Sociedades carnavalescas cariocas em fins do século XIX. In: CUNHA, Maria Clementina Perereira (Org.). Carnavais e outras frestas: ensaios de história social da cultura. Campinas: Editora da Unicamp, 2002.

SOIHET, Rachel. Comparando escritos: Júlia Lopes de Almeida e Carmem Dolores. Caderno Espaço Feminino, v.9, n. 10/11, 2001/2002, p. 85-107.

SODRÉ, Nelson Werneck. História da imprensa no Brasil. Rio de Janeiro: Mauad, 1999 [1966].

VIANA FILHO, Luis. A vida de Rui Barbosa. São Paulo: Nacional, 1949. 


\title{
RESUMO
}

Este artigo examina a atuação de Rui Barbosa no jornal A Imprensa, publicado na cidade do Rio de Janeiro entre 1898 e 1901, e analisa a relação estabelecida entre Rui Barbosa e o advogado Edmundo Bittencourt, proprietário do célebre Correio da Manhã, lançado em 1901. Ainda que esses homens compartilhassem os mesmos ideais políticos, eles o manifestam de formas diferentes, mobilizando estratégias diversas para atingir e aumentar o número de leitores. Assim, embora esses dois jornais difundam os mesmos principios, como a revisão da Constituiçãa, são concebidos de acordo com projetos distintos.

Palavras-chave: imprensa, política, público leitor, República; Rio de Janeiro.

\begin{abstract}
This article analyzes Rui Barbosa participation in the newspaper A Imprensa, published in Rio de Janeiro, between 1898 and 1901. It analyses also the relationship established between Rui Barbosa and the laywer Edmundo Bittencourt, who was the owner of the famous Correio da Manhã, which appeared in 1901. These men shared the same political ideals, but they had different ways to express them and antagonists strategies to reach and to increase the number of readers. Although these newspapers diffuse the same principles, like the revision of the Constitution, they are conceived as independent projects.

Keywords: press, policy, readers, Republic, Rio de Janeiro.
\end{abstract}

